\title{
Bio-efficacy of some insecticides against pest complex of blackgram [Vigna mungo (L.) Hepper]
}

S.G. PARMAR, M.M. NAIK, H.V. PANDYA*1, N.K. RATHOD, S.D. PATEL, P.P. DAVE AND M.M. SAIYAD

Department of Entomology, N.M. College of Agriculture, Navsari Agricultural University, NAVSARI (GUJARAT) INDIA ${ }^{1}$ Department of Entomology, ASPEE College of Horticulture and Forestry, Navsari Agricultural University, NAVSARI (GUJARAT) INDIA

\section{ARITCLE INFO}

Received : 08.12 .2014

Revised : 05.03 .2015

Accepted : 18.03 .2015

\section{KEY WORDS :}

Bio efficacy, Insecticides, Blackgram, Whitefly, Jassid, Aphid, Gram pod borer, Spotted pod borer

*Corresponding author:

Email: hvpandya@nau.in

\begin{abstract}
An investigation was carried out on bio-efficacy of newer insecticides against pest complex of blackgram [Vigna mungo (L.)] at Navsari Agricultural University, Navsari, Gujarat during Kharif season. Among the tested eleven insecticide, the higher effectiveness was observed with the application of clothianidin 50 per cent WDG $(0.003 \%)$ against whitefly, jassid and aphid. While, spinosad $2.5 \mathrm{SC}(0.002 \%)$ was the most effective against gram pod borer and spotted pod borer.

How to view point the article : Parmar, S.G., Naik, M.M., Pandya, H.V., Rathod, N.K., Patel, S.D., Dave, P.P. and Saiyad, M.M. (2015). Bio-efficacy of some insecticides against pest complex of blackgram [Vigna mungo (L.) Hepper]. Internat. J. Plant Protec., 8(1) : 162-168.
\end{abstract}

